\title{
大口径 PHC 杭のせん断終局強度の計算方法に関する研究 THE CALCULATION METHOD FOR THE ULTIMATE SHEAR STRENGTH OF LARGE DIAMETER PHC PILES
}

\author{
岸田慎司*, 堀井昌博**, 桑原文夫***, 林 静雄**** \\ Shinii KISHIDA, Masahiro HORII, Fumio KUWABARA \\ and Shizuo HA YASHI
}

\begin{abstract}
Today, it is necessary to make clear the ultimate shear strength of the PHC piles. In this research, we propose an estimation formula to predict the ultimate shear strength on the PHC piles. The estimation formula shows that the ultimate shear strength is the total of the share of the concrete( $\tau 1)$, the share of the spiral reinforcement $(\tau 2)$, the share of the axial force $(\tau 3)$, and the share of the concrete filled in the hollow part of the piles( $\tau 4$ ). The estimation formula got for the conformability to be better than the experiment formula in the past.
\end{abstract}

\begin{abstract}
Keywords : large diameter PHC pile, ratio of thickness to diameter, composite axial stress, amount of spiral reinforcement, concrete filled in the hollow part of PHC piles, ultimate strength in shear 大口径 PHC 杭, 肉厚と杭径の比, 複合軸方向応力度, らせん筋量, 中詰めコンクリート, せん断終局強度
\end{abstract}

\section{1.はじめに}

建築基準法では基礎構造の耐震設計をする際に終局強度の検 討を義務付けていないので, 中低層の建物に使用されるのがほと んどである遠心力高強度プレストレストコンクリート杭（以下 PHC 杭) 基礎では, 許容応力度設計のみが行われており, 終局 強度に対する安全性の検討は行われていない。

本来杭基礎の耐震設計は, 上部構造の設計法と整合性のとれた 設計法を用い, 上部構造とバランスがとれた性能を確保する必要 が有る。しかし, 今日では杭を強度型, 勒性型のいずれで設計す るにしても, 杭の終局強度に関する研究は少ないため, 杭本体の 耐震性能は明らかでないのが現状である。

現在, 杭のせん断強度に関する研究としては, 杭断面を長方形 断面に置換して計算するせん断終局強度式を提案した研究[1]や， Kani のアーチ理論を修正してせん断終局強度式を提案した研究 [2]などが有るものの, 杭のせん断強度は十分に明らかにされてい ない。現行の日本建築センター指針[3]でも, PHC 杭を使用した 杭基礎では許容応力度設計法に基づいて弾性設計しか行われて いない。

本報は PHC 杭の耐震性能を把握する目的で行われている一 連の研究である。既報[4]では, 現行 JIS 規格の大口径 PHC 杭
の力学的性状に関する実験を行い, 各パラメータがせん断終 局強度に及ぼす影響, 杭自体の力学的性質を明らかにした。 さらに, 前報[5]では, 大口径 PHC 杭について, せん断強度を高 め, 脆性破壊を防止するために, 杭中空部にコンクリートを中詰 めすると共に, らせん筋量を増加させることを提案し, 定軸力下 での逆対称曲げせん断実験を行った。

前報までの実験結果によれば, 杭のせん断終局強度は, 有効プ レストレス量と軸方向外力による応力度の和（複合軸方向応力 度）の影響を受けること，柱のせん断終局強度式を準用した既往 の提案式[1]では, 複合軸方向応力度が大きく, 口径に対する肉厚 の比が小さくなる大口径の場合には, 危険側の評価となる。らせ ん筋量を増加させた場合には, せん断終局強度は上昇するが, 肉 厚によっては耐力の増加は頭打ちになること, 杭中空部にコンク リートを中詰めした場合には, 最大耐力は増加するが脆性的な破 壊をしてしまうこと,らせん筋量を増やしてコンクリートを中詰 めした場合には, 最大耐力も変形性能も改善されること,さらに, 既報[6]の解析結果からは, 肉厚比による最大せん断応力度分布の 違いや, 肉厚の割增がせん断応力集中の緩和に有効であることが 明らかになった。

現行 JIS 規格杭というのは, 外径によって $300 \mathrm{~mm}$ から $1200 \mathrm{~mm}$

\footnotetext{
本研究は参考文献[15]を再構成の上，新たな検討を加之たものである。

* 東京都立大学 助手・博士 (工学)

** 日建設計技術長. 工博

*** 日本工業大学工学部建築学科 教授. 工博

**** 東京工業大学建築物理研究セン夕一 教授. 工博
}

Research Assoc., Tokyo Metropolitan University, Dr. Eng.

Chief Structural Engineer, Nikken Sekkei Ltd., Dr. Eng.

Prof., Nippon Institute of Technology, Dr. Eng.

Prof., Structural Engineering Research Center, Tokyo Institute of Technology, Dr. Eng. 
に区分されている。その中で実験に使用した試験体は，外径が $300 \mathrm{~mm}$ (肉厚 $\mathrm{t}=60 \mathrm{~mm}$ ), $600(\mathrm{t}=90), 900(\mathrm{t}=120), 1200(\mathrm{t}=150)$ の 4 種類を杭径 $300 \mathrm{~mm}$ に縮小し, 肉厚も同じ縮小率で薄くし た杭である。つまり，大口径になるほど杭径に対する肉厚の 比が小さくなっている。

以上の実験結果と解析結果を踏まえて, 本研究では, 大口径の PHC 杭を含めたせん断終局強度の推定式を提案する。

\section{2. せん断終局強度推定式の提案}

\section{1 対象とした実験資料}

せん断終局強度に関する諸検討には既報の実験デー夕 [4]， [5] (100 体) のうち, せん断スパン比が 1.5 で，せん断破壊した試 験体のみを使用し，中詰めコンクリートが無い試験体 57 体，中 詰めコンクリートが有る試験体 9 体を対象に検討した。

なお, 円環断面の最大せん断応力度と矩形断面の最大せん断応 力度の比がほぼ 1.0 に近い值をとるので, 円環断面を図 1 のよう に矩形断面 (be : (2) 式参照) に置換してせん断終局強度を考察 する。

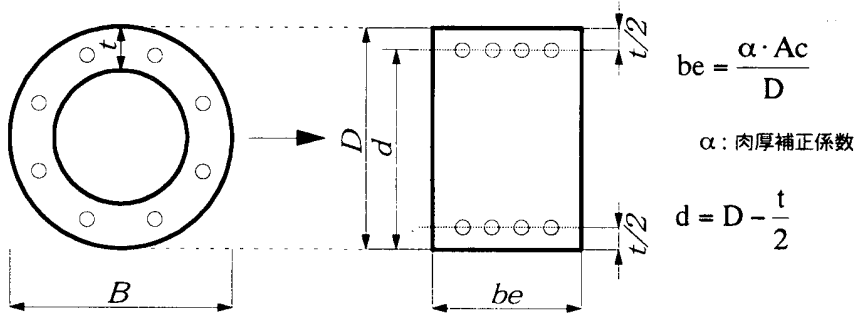

図 1 円環断面から矩形断面への置換

\section{2 肉厚補正係数の説明}

前報まで最大耐力時のせん断応力度を計算するのに, 杭の全断 面積で除して求めていた。しかし，既報[6]の解析結果において， 肉厚の薄い試験体と厚い試験体のせん断応力度分布を比較する と, 両者とも中央部のせん断応力度が高くなっているが, 肉厚の 薄い試験体が肉厚の厚い試験体に比べ, せん断応力度の高い領域 が広く, 集中度合いが高くなっている。さらに, せん断応力度分 布を肉厚方向に見てみると，肉厚の薄い場合と厚い場合とでは， 薄い場合のせん断応力度の勾配が厚い場合よりも急になってい る。従って, 肉厚の違いによる応力度分布を補正することとした。 複合軸方向応力度の影響の小さい 0 種の試験体の中で, 軸力が

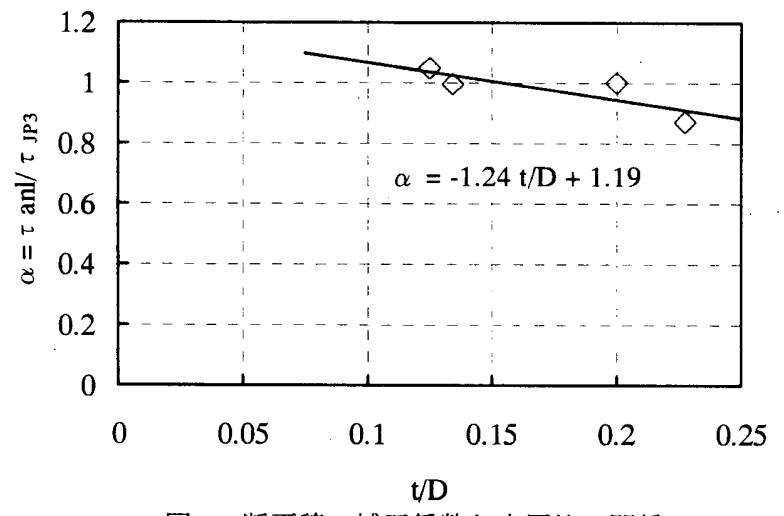

図 2 断面積の補正係数と肉厚比の関係
無く, 肉厚の厚い JP3-00-15 と肉厚の薄い JP12-00-15 の 2 種類に ついて, 肉厚を実測値と公称値として解析した。ここで, 試験体 名 JP3-00-15 において最初の数字は杭の外径を示し, 次の数字は 有効プレストレス量, 3 番目の数字はせん断スパン比を示してい る。詳細は付録 2 を参照のこと。

JP3-00-15 の公称值の肉厚モデルのせん断強度解析值を全コン クリート断面積で除した平均せん断応力度をて JP3 とし，それぞ れの実測值の肉厚モデルのせん断強度解析值をそれそれれ全コ ンクリート断面積で除した平均せん断応力度を $\tau$ anl としたとき, 図 2 はこれらの比 $(\alpha=\tau \mathrm{anl} / \tau \mathrm{JP3})$ と肉厚比 $(\mathrm{t} / \mathrm{D})$ の関係を示し たものである。肉厚が薄い場合には係数 $\alpha$ が大きくなる。肉厚の 薄い試験体と肉厚の厚い試験体の平均せん断応力度分布を等価 にするためには, 実断面積に $\alpha$ を乗じて肉厚の薄い試験体断面積 を大きめに評価すれば良い。

図 2 から求めた近似直線は(1)式となる。

$$
\alpha=-1.24 \frac{\mathrm{t}}{\mathrm{D}}+1.19
$$

\section{3 使用する記号の説明}

(1)有効断面幅（be）を求める。

Ac は実測值による杭断面積で， $\alpha$ は(1)式から得られる肉厚比 による補正係数である。ここでは，D（断面せい）は杭径 $300 \mathrm{~mm}$ とする。

$$
\text { be }=\frac{\alpha \cdot A c}{D} \quad(\mathrm{~mm})
$$

(2)有効せい（d）を求める。

有効せいは圧縮縁から鉄筋までの位置を意味する。尚, 現行 JIS 規格杭の軸方向鉄筋は各杭断面の肉厚の真中に位置していると 考え, 断面せい（D）から肉厚の半分を引くことにより求める。

$$
\mathrm{d}=\mathrm{D}-\frac{\mathrm{t}}{2} \quad(\mathrm{~mm})
$$

(3)応力中心間距離（j）を求める。

有効せいの 7/8 倍を応力中心間距離とする。

$$
\mathrm{j}=\frac{7}{8} \mathrm{~d} \quad(\mathrm{~mm})
$$

(4)主筋比（pg）を求める。

主筋比には鉄筋の全断面積を be·j で除した值を用いる。

$$
\mathrm{pg}=\frac{\mathrm{Ag}}{\mathrm{be} \cdot \mathrm{j}}
$$

\section{$\mathrm{Ag}:$ 軸方向筋全断面積 $\left(\mathrm{mm}^{2}\right)$}

(5)らせん筋比（pw）を求める。

らせん箭比は 1 組のらせん筋断面積 $\left(\mathrm{Aw}: \mathrm{mm}^{2}\right)$ を有効幅 (be) とらせん筋の巻いてあるピッチ（s）で除して求める。なお，ら せん筋比にらせん筋の降伏強度または, 引張強度を乗じた值 （pw・w $\sigma \mathrm{y} ）$ をらせん筋量 [付録 1 参照］と呼ぶ。

$$
\mathrm{pw}=\frac{\mathrm{Aw}}{\mathrm{be} \cdot \mathrm{s}}
$$



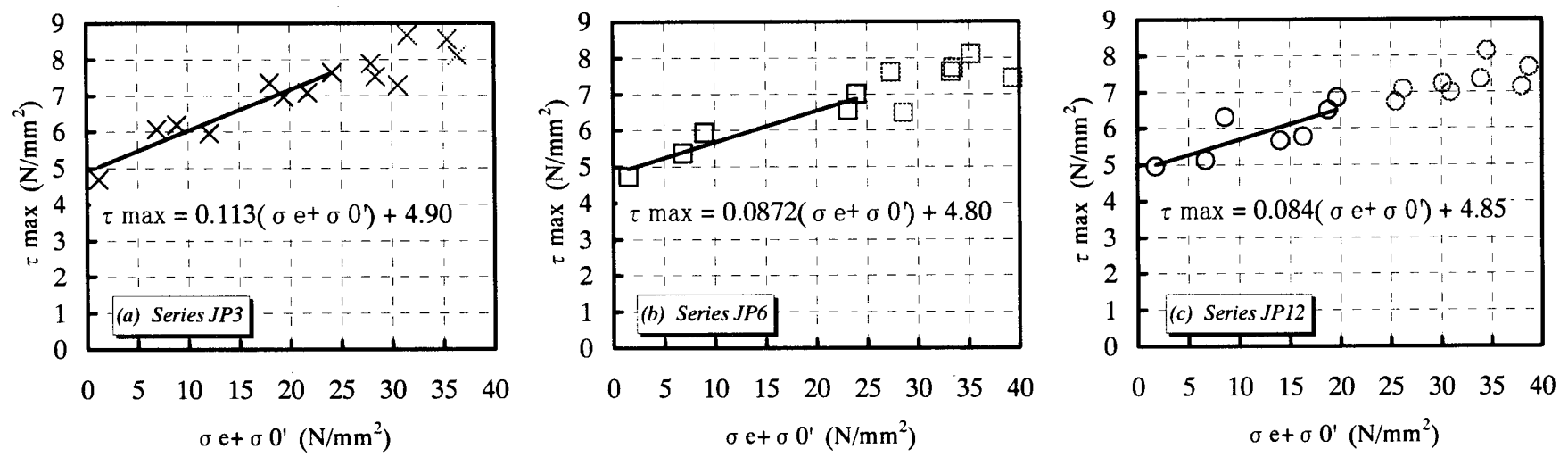

図 3 最大耐力時のせん断応力度と複合軸方向応力度の関係

(6)複合軸方向応力度を求める。

有効プレストレス量 $(\sigma \mathrm{e})$ は杭の製造過程で導入される力な ので, 断面積に有胶に働いているという仮定の下で実測値の全断 面積を使用して求める。軸方向応力度 $\left(\sigma 0^{\circ}\right)$ は杭負担軸方向力 （N）をbe·jで除して求める。

$$
\sigma e+\sigma 0^{\prime}=\sigma e+\frac{\mathrm{N}}{b e \cdot j} \quad\left(\mathrm{~N} / \mathrm{mm}^{2}\right)
$$

杭中空部にコンクリートを中詰めした試験体に軸力を付加し た場合には，軸力を杭負担分（Ns）と中詰めコンクリート負担分 (Nc) とに分けて計算する（(17)式参照)。

$$
\sigma 0^{\prime}=\frac{\mathrm{Ns}}{\mathrm{be} \cdot \mathrm{j}} \quad\left(\mathrm{N} / \mathrm{mm}^{2}\right)
$$

これ以降, $A c^{\prime}=b e \cdot j$ を有効断面積と呼ぶ。本報において $\mathrm{PHC}$ 杭のせん断終局強度とは, 実験值の最大耐力を断面積を補正して 求めた有効断面積（be·j）で除した值を意味している。

\section{2 . 4 複合軸方向応力度の影響}

実験データの中で, 複合軸方向応力度をパラメータにした試 験体が多数有るため, まず, 複合軸方向応力度とせん断終局強度 の関係を見る。

図 3 は杭径に対する肉厚の比が異なるJP3，JP6，JP12 それぞ れの場合の複合軸方向応力度 $\left(\sigma e+\sigma 0^{\prime}\right)$ とせん断終局強度 $(\tau$ $\max =\mathrm{Qmax} / \mathrm{be} \cdot \mathrm{j})$ の関係を示している。この図を見ると,どの肉 厚比の場合でも複合軸方向応力度が増加すると，ほぼ同じ増加率 で $\tau \max も$ 增加している。また, $\sigma \mathrm{e}+\sigma 0^{\prime}$ が零の時も $\tau \max$ の值 は肉厚比によらず同じであった。さらに複合軸方向応力度がある 值以上になるとて max は一定值となる。

図 4 はせん断破壊した全ての試験体のせん断終局強度と複合 軸方向応力度 $\left(\sigma \mathrm{e}+\sigma 0^{\circ}\right)$ の関係を示している。白拔き印が $\sigma \mathrm{e}+$ $\sigma 0$ 夯増加するとせん断終局強度も大きくなる範囲の試験体で, 黒印が， $\sigma e+\sigma 0$ が增加しても $\tau$ max は增加せずに頭打ちの状態 にある試験体である。複合軸方向応力度が $25 \mathrm{~N} / \mathrm{mm}^{2}$ 以下の試験 体と $25 \mathrm{~N} / \mathrm{mm}^{2}$ 以上の試験体に分け, $25 \mathrm{~N} / \mathrm{mm}^{2}$ 以下の試験体につ いては最小二乗法により近似直線を求め, $25 \mathrm{~N} / \mathrm{mm}^{2}$ 以上の試験体 については平均值を求めると次のようになる。

$\sigma e+\sigma 0^{\prime} \leq 25 \mathrm{~N} / \mathrm{mm}^{2}$ の時, $\tau \max =0.102\left(\sigma e+\sigma 0^{\prime}\right)+4.78\left(\mathrm{~N} / \mathrm{mm}^{2}\right)$
$25 \mathrm{~N} / \mathrm{mm}^{2} \leq \sigma e+\sigma 0^{\prime}$ の時,

$$
\tau \max =7.57 \quad\left(\mathrm{~N} / \mathrm{mm}^{2}\right)
$$

図 4 において $\mathrm{y}$ 軸との切片, つまり複合軸方向応力度が零の 時の值は $\tau=4.78 \mathrm{~N} / \mathrm{mm}^{2}$ となり, この值を荒川式[7]を使用して計 算した値と比較したものが表 1 である。軸力 0 の時の荒川式計算 值と 1 割以内の誤差で良く対応している。

ここで, 荒川式のせん断終局強度の考え方を準用して，コン クリート負担分 $(\tau 1)$ ，らせん筋負担分 $(\tau 2)$, 軸力負担分 $(\tau 3)$ そして, 中詰めコンクリート負担分（七4）の和でせん断終局強 度を推定できると考える（(9)式）。ここで, 軸力負担分とは, 複 合軸方向応力度によるせん断強度の増加分のことである。

$$
\begin{array}{r}
\mathrm{Qu}=(\tau 1+\tau 2+\tau 3+\tau 4) \times(\mathrm{be} \cdot \mathrm{j}) \quad(\mathrm{N}) \ldots \ldots \ldots \ldots \ldots \ldots \ldots \ldots \ldots \ldots \\
\tau 1: \text { コンクリート負担分 }\left(\mathrm{N} / \mathrm{mm}^{2}\right)
\end{array}
$$

\begin{tabular}{|c|c|c|}
\hline & 統計值 & 㖕算値 \\
\hline 試験体名 & $\begin{array}{c}\tau \\
\mathrm{N} / \mathrm{mm}^{2}\end{array}$ & $\begin{array}{l}\tau_{\text {䒪㸪式 }} \\
\mathrm{N} / \mathrm{mm}^{2}\end{array}$ \\
\hline JP3-00-15 & & 4.90 \\
\hline$J P 6-00-15$ & & 5.01 \\
\hline$J P 9-00-15$ & & 4.97 \\
\hline$J P 12-00-15$ & & 5.10 \\
\hline 平均 & 4.78 & 5.00 \\
\hline
\end{tabular}

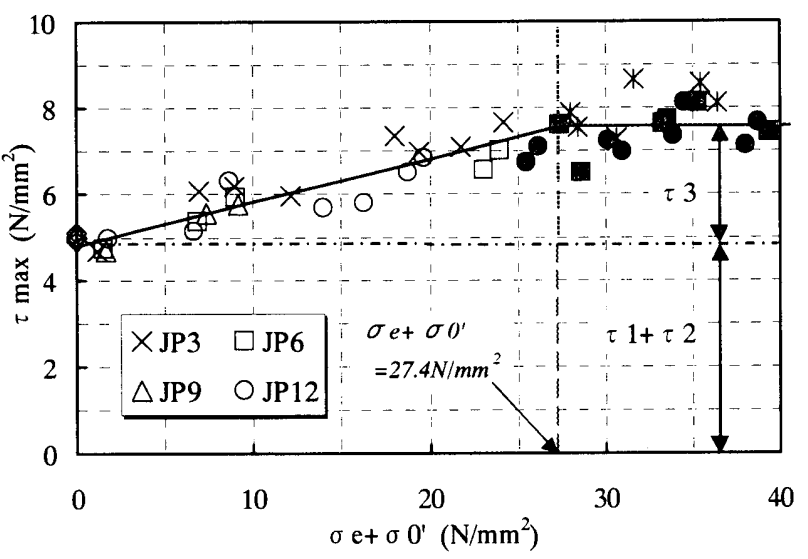

図 4 最大耐力時のせん断応力度と複合軸方向応力度の関係

表 1 複合軸方向応力度が 0 の時の荒川式との対応 


$$
\begin{aligned}
& \tau 2: \text { らせん筋負担分 }\left(\mathrm{N} / \mathrm{mm}^{2}\right) \\
& \tau 3: \text { 軸力負担分 }\left(\mathrm{N} / \mathrm{mm}^{2}\right) \\
& \tau 4: \text { 等価中詰めコンクリート負担分 }\left(\mathrm{N} / \mathrm{mm}^{2}\right)
\end{aligned}
$$

\section{5 コンクリート負担分}

コンクリート負担分は, 表 1 で, 複合軸方向応力度がない時 のせん断応力度と荒川式の第 1 項が良くあっていたことから, 荒 川式の第 1 項(10)式で表すことができる。

$$
\begin{aligned}
& \tau 1=\frac{0.115 \mathrm{ku} \cdot \mathrm{kp}\left(\sigma_{\mathrm{B}}+17.7\right)}{\mathrm{M} / \mathrm{Qd}+0.115} \quad\left(\mathrm{~N} / \mathrm{mm}^{2}\right) \\
& \text { ここで, } \sigma_{\mathrm{B}} \text { : 杭体コンクリート圧縮強度 }\left(\mathrm{N} / \mathrm{mm}^{2}\right) \\
& \mathrm{d}: \text { 有効せい }(\mathrm{mm}) \\
& \mathrm{ku}: \text { 断面寸法による補正係数 }
\end{aligned}
$$

（文献 8：「鉄筋コンクリート構造計算規準・同解説 1991, 日 本建築学会」のp.173 の図 16.3 参照)

$$
\text { 今回の寸法の範囲内では, }\left\{\begin{array}{l}
\mathrm{d}=260 \mathrm{~mm} \cdots \mathrm{ku}=0.83 \\
\mathrm{~d}=270 \mathrm{~mm} \cdots \mathrm{ku}=0.82 \\
\mathrm{~d}=280 \mathrm{~mm} \cdots \mathrm{ku}=0.80
\end{array}\right.
$$

$\mathrm{kp}$ : 引張鉄筋比 $\mathrm{pt}$ による補正係数

$$
\mathrm{kp}=0.82(100 \mathrm{pt})^{0.23}, \quad \mathrm{pt}=\frac{\mathrm{pg}}{4} \quad, \quad \mathrm{pg}=\frac{\mathrm{Ag}}{\mathrm{be} \cdot \mathrm{j}}
$$

\section{6 軸力負担分}

軸力負担分は 2.4 章 $(8 \cdot 1),(8 \cdot 2)$ 式より $(11 \cdot 1),(11 \cdot 2)$ 式で表 されるものとする。

複合軸方向応力度が $25 \mathrm{~N} / \mathrm{mm}^{2}$ 以下の試験体と $25 \mathrm{~N} / \mathrm{mm}^{2}$ 以上の 試験体に分けて, $25 \mathrm{~N} / \mathrm{mm}^{2}$ 以下の試験体には最小二乗法により近 似直線を求め, その時の複合軸方向応力度による増加分を $\tau 3$ と して, $\sigma \mathrm{e}+\sigma 0$ が $27.4 \mathrm{~N} / \mathrm{mm}^{2}$ 以上では， $\tau 3=2.79 \mathrm{~N} / \mathrm{mm}^{2}$ の一定值 をとる形にする。

$$
\begin{aligned}
& \sigma e+\sigma 0^{\prime} \leq 27.4 \mathrm{~N} / \mathrm{mm}^{2} \text { の時, } \\
& \tau 3=0.102\left(\sigma e+\sigma 0^{\prime}\right) \quad\left(\mathrm{N} / \mathrm{mm}^{2}\right) \quad \cdots \cdots \cdots \cdots(11 \cdot 1) \\
& 27.4 \mathrm{~N} / \mathrm{mm}^{2} \leq \sigma e+\sigma 0^{\prime} \text { の時, } \\
& \tau 3=2.79 \quad\left(\mathrm{~N} / \mathrm{mm}^{2}\right)
\end{aligned}
$$

図 5 は解析による最大せん断応力度[6],[16]と断面補正して求

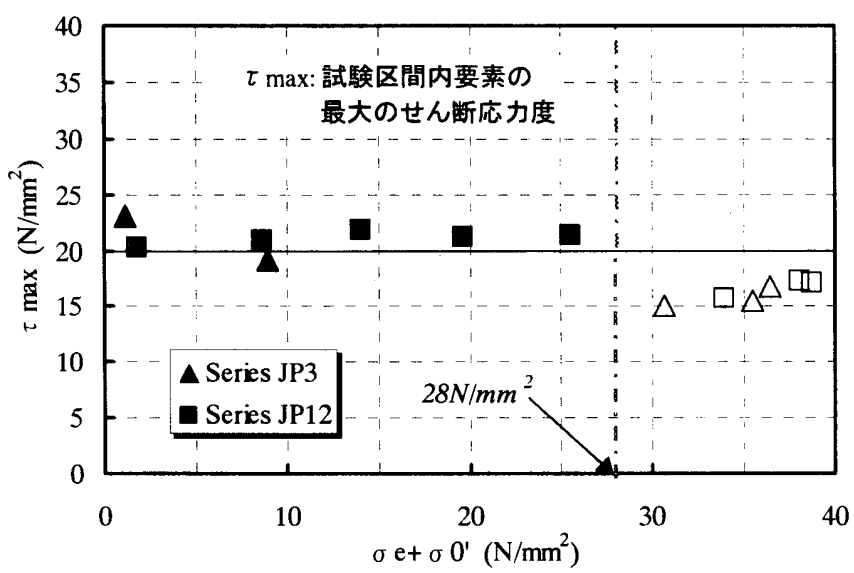

図 5 最大せん断応力度（解析值）と複合軸方向応力度の関係
めた複合軸方向応力度との関係を示している。黒印がせん断破壊 した試験体で, 白抜き印が圧縮破壊, せん断一圧縮破壊した試験 体である。これを見ると複合軸方向応力度が約 $28 \mathrm{~N} / \mathrm{mm}^{2}$ を境に 破壊形式が変わっている。せん断終局強度の頭打ちの境界として, 複合軸方向応力度が $27.4 \mathrm{~N} / \mathrm{mm}^{2}$ とすることの妥当性が, 解析から も裏付けられたものと考える。

\section{7 ら世ん筋負担分}

図 6 は実験值のせん断終局強度（exp $\tau$ max）から，コンクリ 一ト負担分 $(\tau 1)$ と軸力負担分（ $23 ）$ を引いた，らせん筋負担 分 $(\tau 2)$ とらせん筋量 $(0.785 \mathrm{pw} \cdot \mathrm{w} \sigma \mathrm{y})$ との関係を示している。

らせん筋比を求める際にせん断補強筋形状が円形であること により, 長方形の場合に比べその補強効果が減じられるというこ とが文献 2 で報告されているので, ここでも, pw·w $\sigma \mathrm{y}$ の值を $\pi / 4(=0.785)$ 倍に低減している。

この図を見るとらせん筋負担分の 22 は $0.785 \mathrm{pw} \cdot \mathrm{w} \sigma \mathrm{y}$ が $7.4 \mathrm{~N} / \mathrm{mm}^{2}$ まではらせん筋量の増加とともに直線的に増加する。 $7.4 \mathrm{~N} / \mathrm{mm}^{2}$ を超えると 2 のばらつきは大きいが，らせん筋量が増 加しても 22 は，ほぼ $4.87 \mathrm{~N} / \mathrm{mm}^{2}$ の一定值となる。なお，図中に 荒川式のときのらせん筋負担分の計算式を示している。これを見 ると，荒川式は下限值を示しているのがわかる。

らせん筋負担分は(12·1)，(12·2)式で表すことができる。

$0.785 \mathrm{pw} \cdot \mathrm{w \sigma y} \leq 7.4 \mathrm{~N} / \mathrm{mm}^{2}$ の時, $\tau 2=0.657 \times(0.785 \mathrm{pw} \cdot \mathrm{w} \sigma \mathrm{y}) \quad\left(\mathrm{N} / \mathrm{mm}^{2}\right) \cdots(12 \cdot 1)$

$7.4 \mathrm{~N} / \mathrm{mm}^{2} \leq 0.785 \mathrm{pw} \cdot$ woy $の$ 時, $\tau 2=4.87 \quad\left(\mathrm{~N} / \mathrm{mm}^{2}\right)$

$\mathrm{pw}:$ らせん筋比, $\mathrm{pw}=\frac{\mathrm{Aw}}{\mathrm{be} \cdot \mathrm{s}}$

Aw : 1 組のらせん筋の断面積 $\left(\mathrm{mm}^{2}\right)$

$\mathrm{s}$ : らせん筋間隔 $(\mathrm{mm})$

※) $\mathrm{pw} \cdot \mathrm{w} \sigma \mathrm{y}$ の値を $\pi / 4 （=0.785 ）$ 倍に低減する

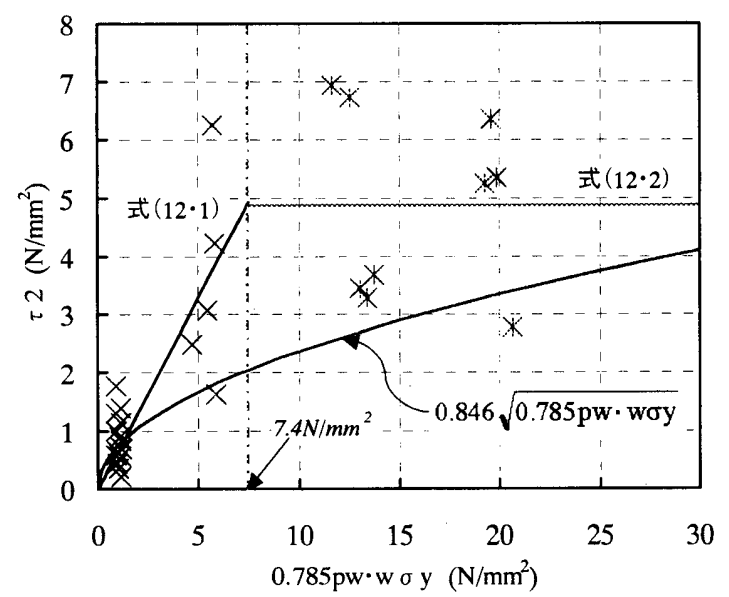

図 6 らせん筋負担分 $(\tau 2)$ とらせん筋量の関係

\section{8 中詰めコンクリート負担分}

中詰めコンクリートを施した試験体のうち，せん断破壊した 試験体を対象に考える。

実験値の最大耐力 $(\mathrm{Qmax})$ から本章で提案した推定式から計 
算した値を引いた値を中詰めコンクリート負担耐力（Q4）とす る。Q4 を中詰めコンクリートの断面積（A 中）で割った值を中詰 めコンクリート負担分 $\left(\tau 4^{\prime}\right)$ とする。

$\mathrm{Q} 4=\mathrm{Q} \max -(\tau 1+\tau 2+\tau 3) \times(\mathrm{be} \cdot \mathrm{j}) \quad(\mathrm{kN})$

$\tau 4^{\prime}=\frac{\mathrm{Q} 4}{\mathrm{~A}_{\text {中 }}} \quad\left(\mathrm{N} / \mathrm{mm}^{2}\right)$

$\mathrm{A}$ 中 : 中詰めコンクリートの断面積 $\left(\mathrm{mm}^{2}\right)$

$\mathrm{Q} 4=\tau 4 \times(\mathrm{be} \cdot \mathrm{j})$ であるので,

$$
\tau 4=\tau 4^{\prime} \times \frac{A_{\text {中 }}}{b e \cdot j} \quad\left(\mathrm{~N} / \mathrm{mm}^{2}\right)
$$

図 7 は中詰めコンクリート負担分 $\left(\tau 4^{\prime}\right)$ と中詰めコンクリー トが負担する軸方向応力度（中 $\sigma 0 ）$ の関係を示したもので，そ れぞれ中詰めコンクリート圧縮強度で除している。 おさまっており, 中詰めコンクリートの軸力比 (中 $\sigma 0 /$ 中 $\sigma \mathrm{c}$ ) で, 中詰めコンクリート負担分比 $\left(\tau 4^{\prime} /\right.$ 中 $\left.\sigma \mathrm{c}\right)$ を表現できると考える ((16)式)。

$$
\frac{\tau 4^{\prime}}{{ }_{\text {中 }} \sigma_{\mathrm{c}}}=0.312 \frac{{ }_{\text {q }} \sigma_{0}}{{ }_{\text {q }} \sigma_{\mathrm{c}}}+0.01
$$

中 $\sigma \mathrm{c}$ : 中詰めコンクリートのコンクリート圧縮強度 $\left(\mathrm{N} / \mathrm{mm}^{2}\right)$ 中 $\sigma 0:$ 中詰めコンクリート負担分の軸方向応力度 $\left(\mathrm{N} / \mathrm{mm}^{2}\right)$

$$
{ }_{\phi} \sigma_{0}=\frac{N c}{A_{\text {中 }}}=\frac{E_{\text {q }}}{A_{\text {中 }} \cdot E_{\text {中 }}+A_{\text {杭 }} \cdot E_{\text {杭 }}} N
$$

$\mathrm{Nc}$ ：中詰めコンクリート負担分の軸力 $(\mathrm{N})$

$\mathrm{A}$ 中 : 中詰めコンクリート断面積 $\left(\mathrm{mm}^{2}\right)$

$\mathrm{E}$ 中 : 中詰めコンクリートのヤング係数 $\left(\mathrm{N} / \mathrm{mm}^{2}\right)$

A 杭 : 杭断面積 $\left(\mathrm{mm}^{2}\right)$

$\mathrm{E}$ 杭 : 杭のヤング係数 $\left(\mathrm{N} / \mathrm{mm}^{2}\right)$

図中○で囲んだ試験体は，肉厚が厚く高軸力の試験体である。 肉厚が厚く高軸力であることから, 中詰めコンクリートの拘束度 が特に高く, コンクリート圧縮強度が上昇したために, 中詰めコ ンクリートのせん断強度が他の試験体と比べて高くなったと思 われる。

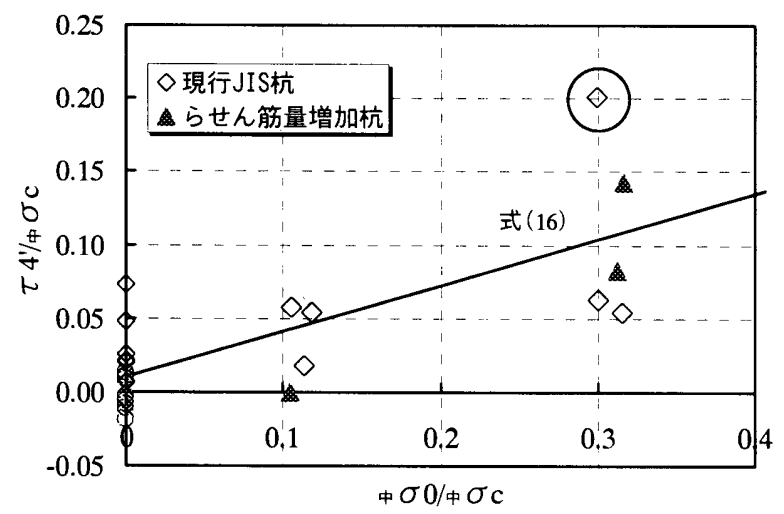

図7 中詰めコンクリートの軸力比 (中 $\sigma 0 /$ 中 $\sigma \mathrm{c})$ と 中詰めコンクリート負担分比（ $\tau 4^{\prime} /$ /中 $\sigma \mathrm{c} ）$ の関係

\section{3. 提案式の精度の検証}
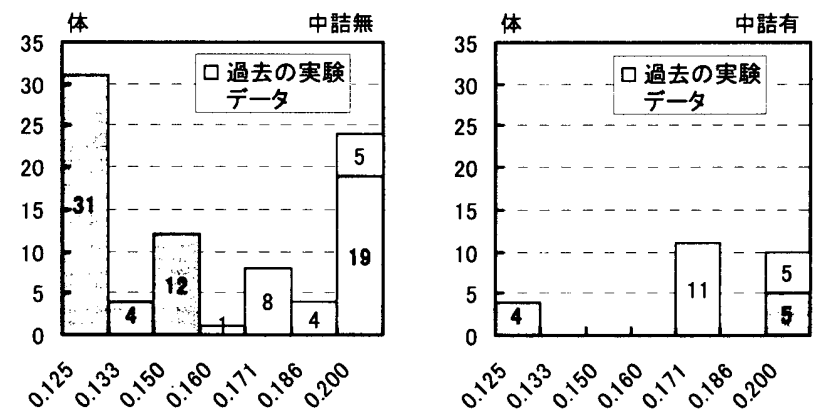

(a)肉厚比 $(t / D)$
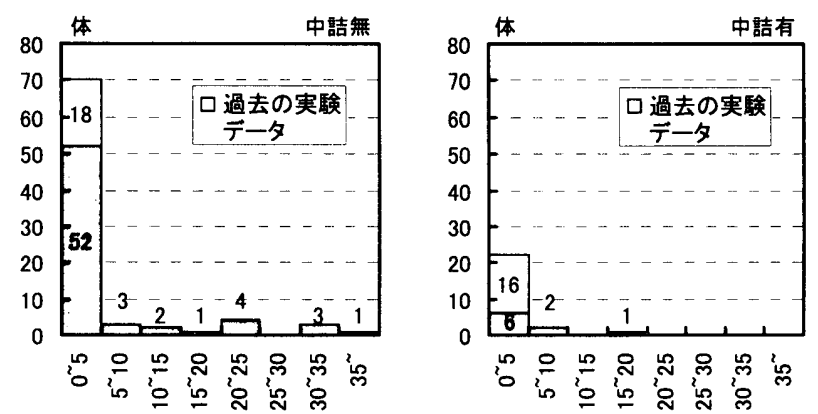

(b)らせん筋量 $\left(\mathrm{pw} \cdot \mathrm{w} \sigma \mathrm{y}: \mathrm{N} / \mathrm{mm}^{2}\right)$
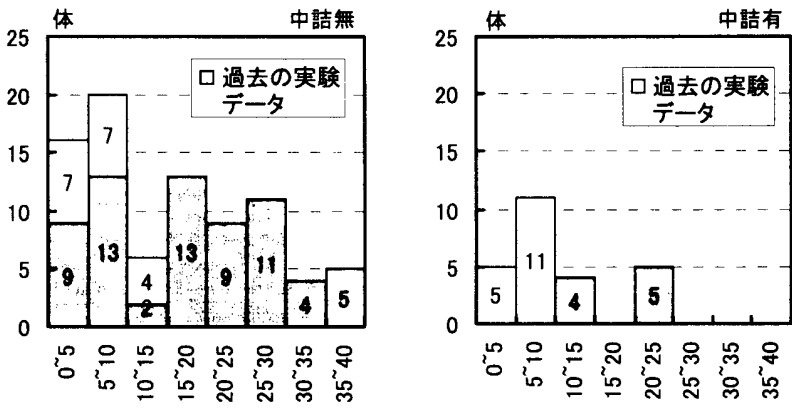

(c)複合軸方向応力度 $\left(\sigma e+\sigma 0^{\prime}: \mathrm{N} / \mathrm{mm}^{2}\right)$

図 8 実験要因の度数分布

検討には, 文献[9]〜[13]に掲載されている過去の実験データ 51 体と筆者等の行った実験結果 100 体のうち, せん断破壊した試験 体のみ総数 109 体 (中詰めコンクリートの無: 84 体, 有 : 25 体) を使用した。なおここでは逆対称加力形式による実験を行った 試験体のみを採用している。

図 8(a)〜(c)にこれらの実験資料における主要因子の度数分布 の一覧を示す。グラフ中色がついているのが筆者等が行った実験 の試験体を示している。

ここには載せていないが，せん断スパン比に関しては，0.5〜 2.3 まであるが, 1.5 の試験体がほとんである。複合軸方向応力度 に関しては試験体がバランス良くあるが，らせん筋量は 0〜 $5 \mathrm{~N} / \mathrm{mm}^{2}$ に集中している。全体的に中詰めコンクリートの試験体 数が少ないことがわかる。

\section{1 中詰めコンクリートの無い場合}

ここでは，現在までに提案されている PHC 杭のせん断終局強 度式のうち, 円環断面を長方形断面に置換して計算する文献 1 の 推算式と今回提案した提案式,2つの計算式の精度を示す。なお, 今回提案した計算式と文献 1 の推算式との違いは以下に示すと おりである。 
1） 円環断面を矩断面に置換す る時に杭幅 (b) に肉厚比の 影響 ( $\alpha$ : 肉厚補正係数) を考慮して, 有効断面幅 (be) としたこと。

2) 主筋比 $(\mathrm{pg})$ ，らせん筋比 (pw), 軸方向応力度 $\left(\sigma 0^{\prime}\right)$ を計算する際に有効断面積 （be·j）を使用しているこ と。

3）らせん筋負担分のせん断強

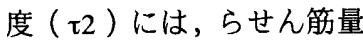
(pw・w $\sigma \mathrm{y})$ の值によって 2 式に分けて表しているこ と。

4) 軸力負担分のせん断強度

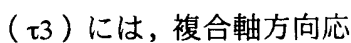
力度 $\left(\sigma e+\sigma 0^{\prime}\right)$ の値によ って 2 式に分けて表してい ること。

図 9 は実験値と文献 1 の推算 式による計算值 (AQcal), 図 10 が実験値と今回提案した提案式 による計算值を示している。

推算式による計算値は平均値 が 1.282 で, 相関係数が 0.871 ， 変動係数が $15.4 \%$ となって, 計 算值 $\pm 20 \%$ 以内の資料数讨全数 の $35.7 \%$ である一方，提案式 による計算値は平均值が 0.992 で, 相関係数が 0.921 , 変動係数 は $11.8 \%$ となっておうり，さらに 提案式の方は土 $20 \%$ 以内の資料 数が $92.9 \%$ となって, 提案式の 方が実験値との相関性が良いこ とがわかる。図中のは既往の 実験デー夕を示しており，これ らの実験結果も今回提案した計 算式と良く対応しているのが解 かる。

文献 1 の推算式では, 全体的 に安全側の評価となっているが, らせん筋量を增やした試験体の 適合性が悪い。一方, 今回の提 案式は, らせん筋量を増やした 場合の試験体においてもせん断 終局強度を的確に表現している。

なお，資料のばらつきを正規 分布と見なして不合格率 5\%に 対応する低減係数を求めると，
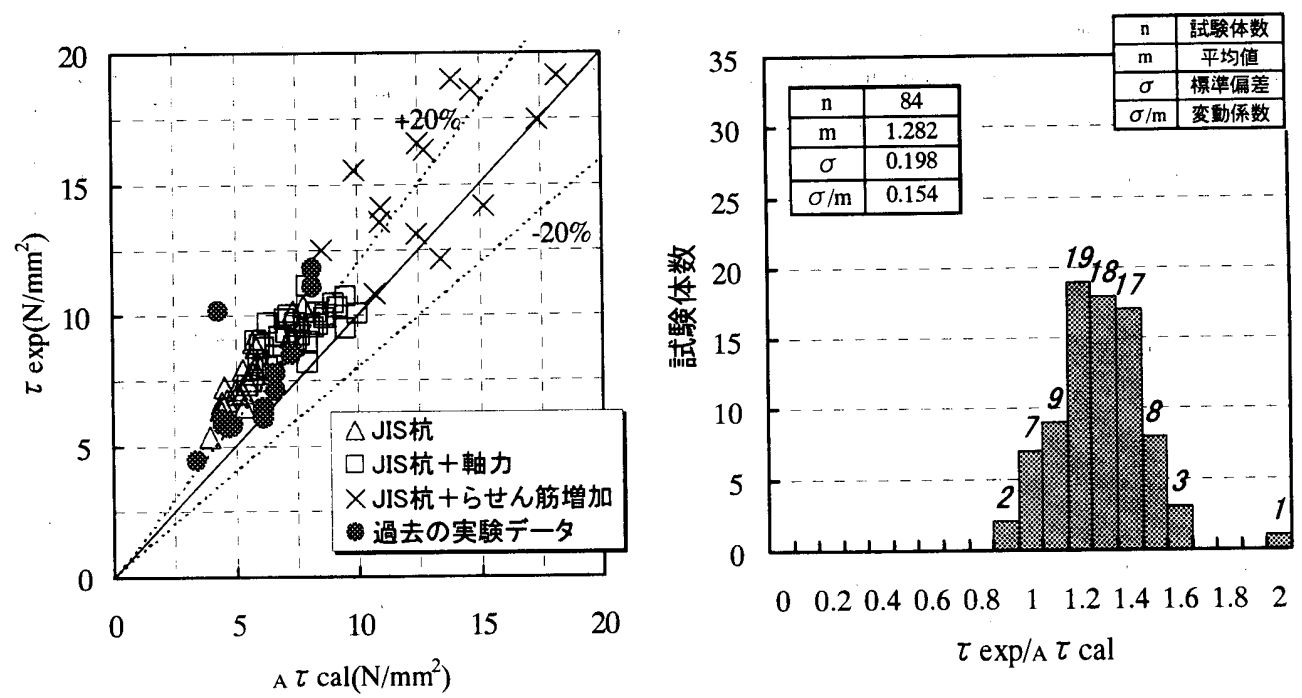

(中詰めコンクリートの無い場合)

図 9 実験佔と計算値 (A $\tau$ cal $=\mathrm{AQcal} / \mathrm{bd})$ との比較
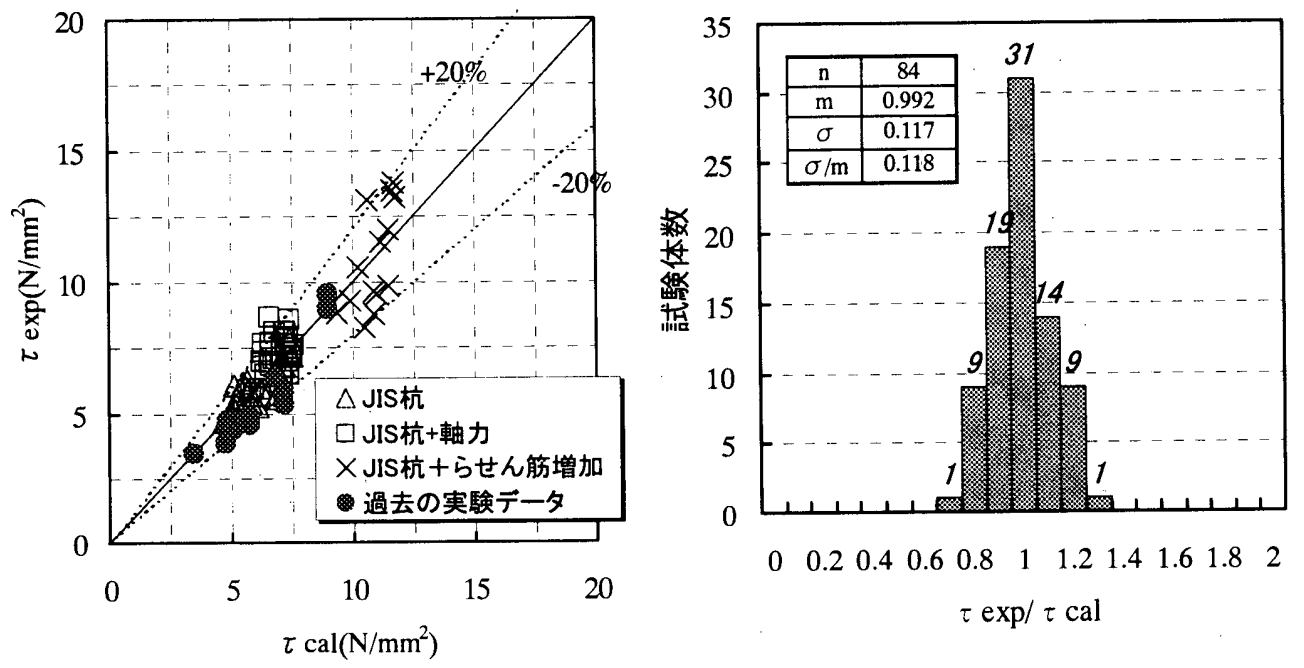

（中詰めコンクリートの無い場合）

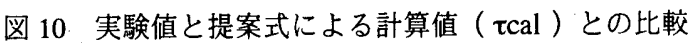
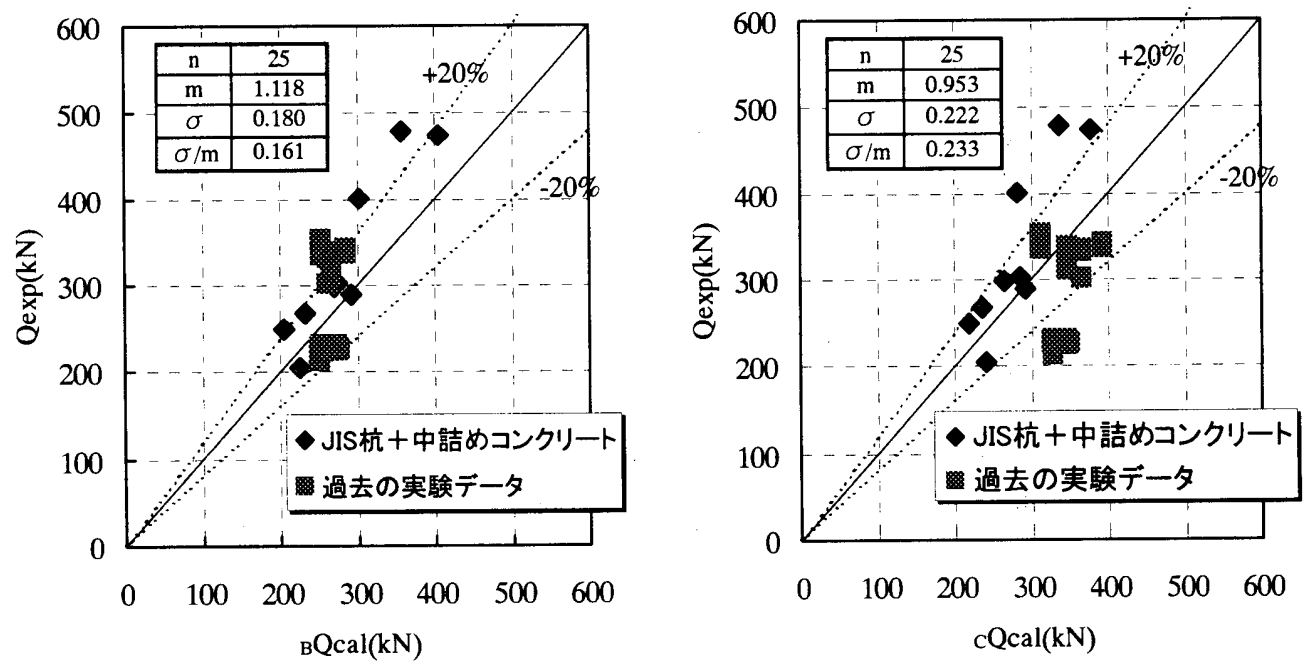

(中詰めコンクリートの有る場合)

図 11 実験值と計算値 (BQcal) との比較 
推算式の場合が 0.956 ，提案式の場合が 0.800 である。

\section{2 中詰めコンクリートの有る場合}

杭の中空部にコンクリートを中詰めした場合のせん断終局強 度は,杭と中詰めコンクリートの合成材と考える計算式 BQcal[12] とコンクリートの等価強度を利用した式 cQcal[14]とがある。各 計算式は既報[5]の付録 3 中の式を使用した。

図 11，12 は中詰めコンクリートの有る試験体の実験値と計算 值（BQcal，cQcal）との比較を示す。杭のせん断強度と中詰めコ ンクリートのせん断強度の累加であるという計算式（BQcal）の 方が変動係数が $16.1 \%$ と良い。

図 12 の等価コンクリート強度を使用した計算值（cQcal）との 比較では変動係数が $23.3 \%$ と大きくなって適合性が悪くなって いる。

図 13 は, 今回提案した提案式による計算值と実験値との比較 を示している。変動係数が $12.5 \%$, 平均も 0.961 と 3 つの式の中 で適合性が良く，士20\%以内の資料数が $92.0 \%$ となっている。

3 つの計算式の中で, 今回提案した提案式の適合性が良いこと がわかる。しかし，中詰めコンクリートを施して，軸力を加えた 実験データが少ないので，今後のデータの蓄積を望みたい。

付録 4 に本提案式をまとめて示す。

\section{4. まとめ}

本論文において，大口径の杭を含めた現行の PHC 杭の実験結 果や杭体中空部にコンクリートを中詰めすること,さらにらせん 筋量を增やすことによる効果について行った実験, 解析結果をも とに提案したせん断終局強度式に関してまとめると以下のよう になる。

（1）既報の実験結果と解析結果を踏まえて，現行JIS規格の大 口径PHC杭のせん断終局強度に対して考察を行い, PHC杭 のせん断終局強度の推定式を提案した。提案した推定式は, コンクリート負担分, らせん筋負担分, 軸力負担分の和と して表現した。

（2）軸力負担分，らせん筋負担分のせん断強度には，ある值以 上では，頭打ちの傾向となるので条件をつけて表現した。

（3）杭の中空部にコンクリートを中詰めした場合のせん断終 局強度は, 先の推定式に中詰めコンクリートの負担分を累 加する形で推定できた。

（4）今回提案した推定式は，既往の実験結果も含めて，せん断 終局強度との適合性が良いものとなった。

今後の課題としては, 今回の提案式は一部 3 次元有限要素法に よる解析で検証はしているが，あくまでも実験結果に拠つている。 力学モデルに立脚したせん断終局強度式を考える上でも，3 次元 有限要素法などを利用して杭体内部の力学性状や，せん断破壊に 至るまでのメカニズムを把握する必要があると考える。

【謝辞】本研究を行うにあたり, 東京理科大学の岸田英明教授, 日本 工業大学の白石一郎助教授, 日建設計の斉藤安生氏に適切なる御指導を 賜りました。また, 本研究は東京工業大学建築物理研究センターの共同 研究の一貫として行われたものであり, COPITA との協同研究でもあり ます。なお，本研究は文部省科学研究費補助金の援助を受けており，筆 頭著者は学術振興会の特別研究員でした。ここに関係者各位に対しまし て深く感謝の意を表します。

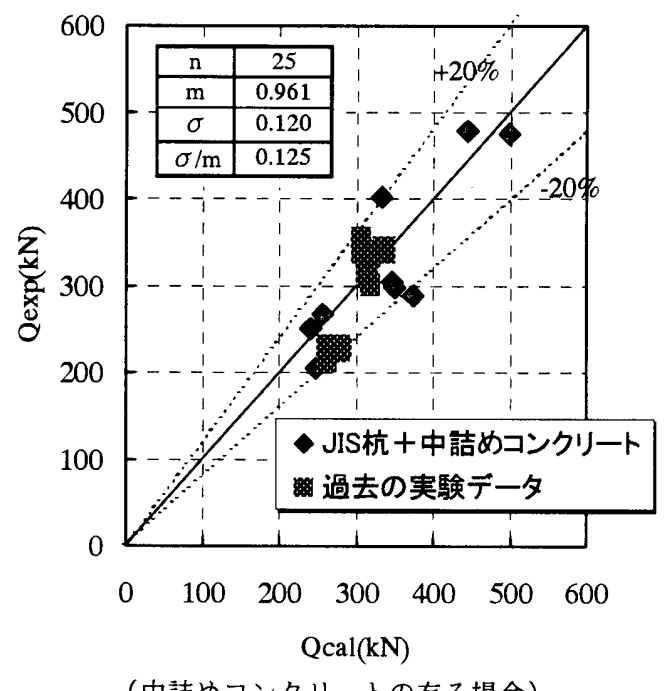

(中詰めコンクリートの有る場合)

図 13 実験値と提案式による計算値（Qcal）との比較

【参考文献】

[1]後藤康明他：遠心力 PC (PHC) 杭剪断耐力推算式, 日本建築学会大会学術 讙演梗概集，pp.983〜984，1985.10

[2]渡辺史夫他 : 曲げとせん断を受ける PCパイルの耐力評価に関する研究，コ ンクリート工学年次論文報告集，9-2, pp.483〜488，1987

[3]地震力に対する建築物の基礎の設計指針，日本建築センター

[4]岸田慎司他 : 大口径 PHC 杭のせん断強度に関する実験研究, 日本建築学会

粠造系論文集, No.510，pp.123 130，1998.8

[5]岸田慎司他 : 大口径 PHC 杭のせん断強度と終局変形性状の改善に閲する実 験研究，日本建築学会粠造系論文集，No.521，pp.81 88，1999.7

[6]山本直孝他 : 大口径 PHC 杭のせん断破猿性状に関する解析的研究，コンク リート工学年次論文報告集，20-3，pp.379 384，1998

[7]荒川 卓：鉄筋コンクリートはりのせん断抵抗に関する研究，北海道大学 工学部研究報告, No.25, 1961.3

[8]鉄筋コンクリート棬造計算規準・同解説 1991, 日本建築学会

[9]山田 悟他: 高強度 PC くいのせん断耐力とそのせん断試験方法，日本建築 学会大会学術㳟演梗概集，pp.2057 2058，1980.9

[10]倉橋修雄他：PC 杭の曲け剪断抵抗性状について (軸力 $\sigma_{0}=0$ の場合), 日本建築学会大会学術講演梗概集，pp.1559 1560， 1981.9

[11]小澤照彦他：フーチングに接合した高強度 PC 杭の耐力・変形性能，日本 建築学会大会学術講演梗摡集，pp.1749 1750，1982.10

[12]菊地 優他：遠心力 PHC 杭のコンクリート充填効果について，日本建築 学会大会学術講演梗概集, pp.981〜982，1985.10

[13]後藤康明他：PHC 杭（C 種）のコンクリート充填効果について，日本建築 学会大会学術講演梗概集, pp.1249 1250，1986.8

[14]建築耐震設計における保有耐力と変形性能，日本建築学会

[15]岸田愪司他：大口径 PHC 杭のせん断強度に關する実験研究，(その 7 : せ ん断終局強度推定式の提案)，(その 8 : 提案式の精度の検討)，日本建築学 会大会学術諲演梗概集，pp.555 558，1999.9

[16]岸田慣司: 大口径高強度プレストレストコンクリート杭のせん断強度に関 する研究，東京工業大学学位論文，1999.3

\section{【付録 1 らせん筋量について】}

PHC 杭のらせん筋にはJIS G 3532 に規定する普通鉄線（SWM-B 及び SWM-F) 又は溶接金網用鉄線 (SWM-P) を使用しており，この鉄線の機 械的性質は引張強さを使用しているので，らせん筋量 (pw·w $\sigma \mathrm{y})$ を求 める際にも woy に引張強度を使用する。たたし，今回の実験において 添え巻きに用いている細径異形 PC 鋼棒（JIS G 3137）には，woyに降 伏強度を使用している。

\section{【付録 2 試験体名の説明】}

(例) JP3 $*^{1}-00 *^{2}-15^{*^{3}}$

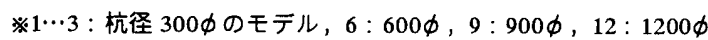
$※ 2 \cdots 40$ : 有効プレストレス量が $\mathrm{A}$ 種， $80: \mathrm{B}$ 種，100：C 種， $00 ： 0$ 種 (筆者等が実験の際に新たに設定，[4]参照）

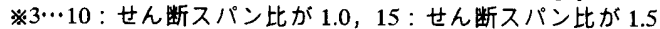


【付録 3 各種せん断強度式】

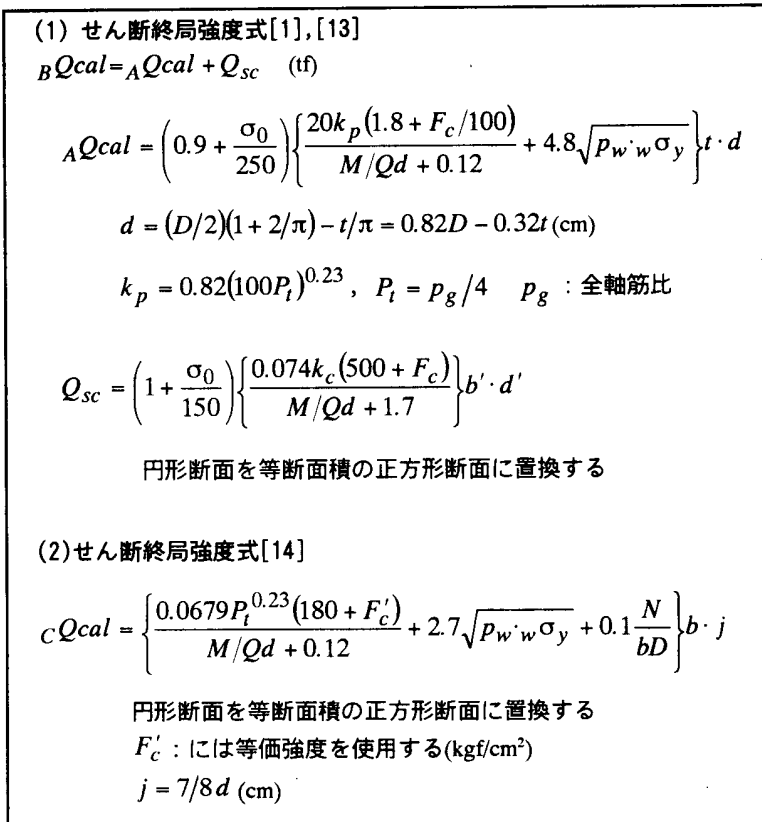

【付録 4 せん断終局強度の提案】

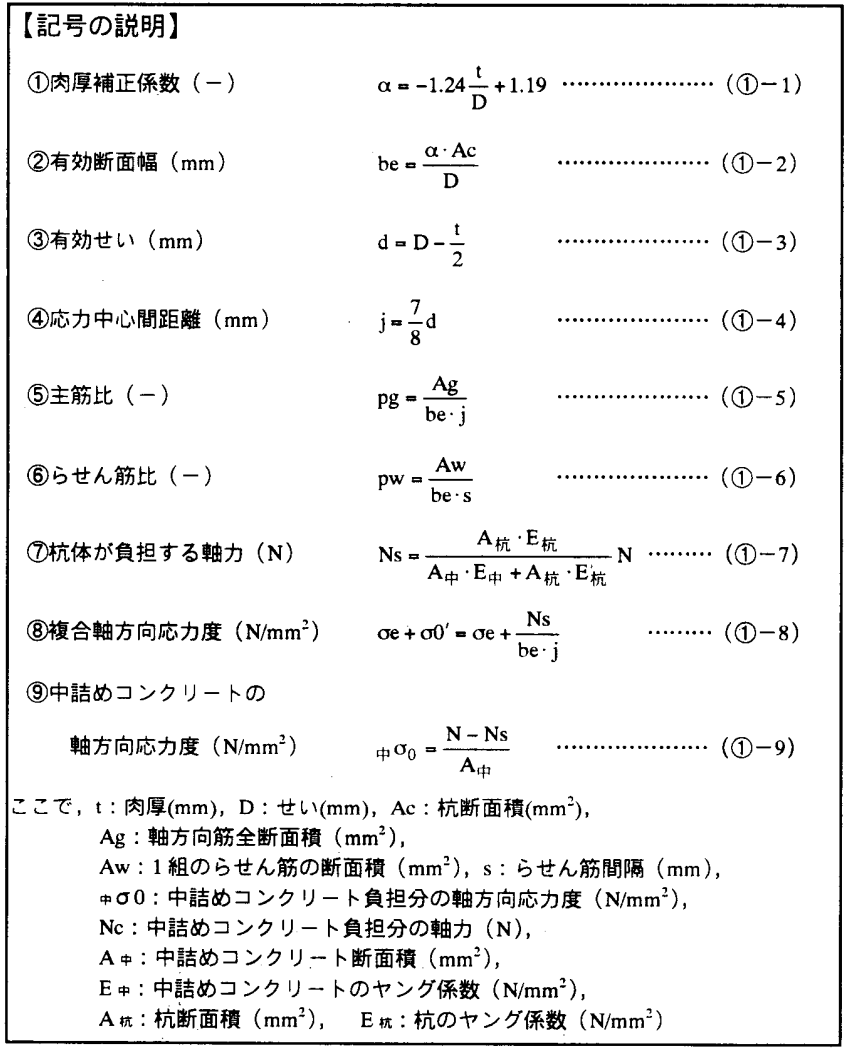

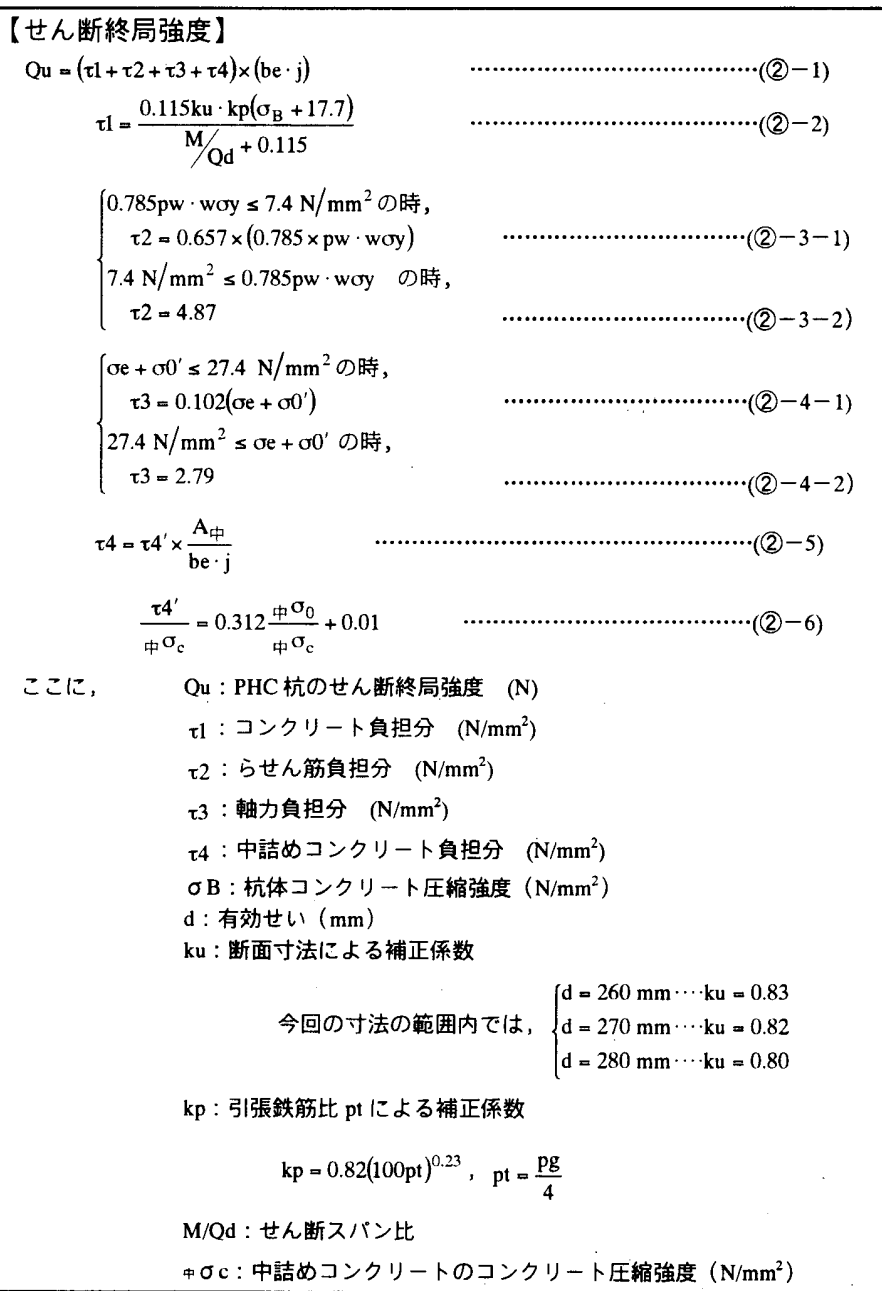

